\title{
The erosion of relational values resulting from landscape simplification
}

\author{
Maraja Riechers $(\mathbb{D}$ - Ágnes Balázsi • Lydia Betz • Tolera S. Jiren • \\ Joern Fischer
}

Received: 21 November 2019/Accepted: 9 April 2020/Published online: 20 April 2020

(C) The Author(s) 2020

\begin{abstract}
Context The global trend of landscape simplification for industrial agriculture is known to cause losses in biodiversity and ecosystem service diversity. Despite these problems being widely known, status quo trajectories driven by global economic growth and changing diets continue to lead to further landscape simplification.

Objectives In this perspective article, we argue that landscape simplification has negative consequences for a range of relational values, affecting the socialecological relationships between people and nature, as well as the social relationships among people. A focus
\end{abstract}

Maraja Riechers and Joern Fischer have equally contributed to the development of this paper and can be contacted as corresponding authors.

M. Riechers $(\bowtie) \cdot$ T. S. Jiren · J. Fischer $(\bowtie)$

Faculty of Sustainability, Leuphana University

Lueneburg, Universitätsallee 1, 21335 Lueneburg,

Germany

e-mail: riechers@leuphana.de

J. Fischer

e-mail: joern.fischer@uni.leuphana.de

\section{Á. Balázsi}

Ecosystem Services Laboratory, Sapientia Hungarian University of Transylvania, Cluj-Napoca, Romania

L. Betz

Agroecology, Department of Crop Sciences, Georg-

August University Goettingen, Goettingen, Germany on relational values has been proposed to overcome the divide between intrinsic and instrumental values that people gain from nature.

Results We use a landscape sustainability science framing to examine the interconnections between ecological and social changes taking place in rural landscapes. We propose that increasingly rapid and extreme landscape simplification erodes human-nature connectedness, social relations, and the sense of agency of inhabitants-potentially to the point of severe erosion of relational values in extreme cases. We illustrate these hypothesized changes through four case studies from across the globe. Leaving the links between ecological, social-ecological and social dimensions of landscape change unattended could exacerbate disconnection from nature.

Conclusion A relational values perspective can shed new light on managing and restoring landscapes. Landscape sustainability science is ideally placed as an integrative space that can connect relevant insights from landscape ecology and work on relational values. We see local agency as a likely key ingredient to landscape sustainability that should be actively fostered in conservation and restoration projects.

Keywords Agricultural intensification - Diversified farming $\cdot$ Human-nature connections $\cdot$ Landscape sustainability science $\cdot$ Smallholder farming $\cdot$ Socialecological systems 


\section{Introduction}

Landscape sustainability science combines the insights from landscape ecology (Forman and Wilson 1995; Wu and Hobbs 2002) with the insights from sustainability science (Kates et al. 2001; Lang et al. 2012) in order to generate place-based solutions to interlinked environmental, social and economic challenges (Wu 2013). Through its focus on the landscape scale, landscape sustainability science provides a powerful and much needed space to integrate the insights from numerous scientific disciplines in ways that are of direct practical benefit to real-world actors and outcomes (Fischer et al. 2014b). In this perspective article, we use a landscape sustainability science framing to examine the interconnections between ecological and social changes taking place in rural landscapes. Throughout this article, we adopt a perspective of strong sustainability, that is, we recognize that ultimately, humanity is dependent on functioning ecosystems in order to maintain social wellbeing and economic activity (see, for example, Fischer et al. 2007; Wu 2013).

Landscape simplification-most notably for the expansion of industrial agriculture-has long been recognized as a key threat to terrestrial ecosystems, affecting wild biodiversity (Green et al. 2005), farmland biodiversity (Tscharntke et al. 2005), and the diversity of crop varieties (FAO 2011). Traditional agricultural landscapes often provide a balance of provisioning, regulating and cultural ecosystem services. Simplified agricultural landscapes, in contrast, largely supply the single provisioning service of crop production-at the expense of other types of services (Foley et al. 2005).

Despite these problems being widely known, status quo trajectories driven by global economic growth and changing diets continue to lead to further landscape simplification (e.g. Foley et al. 2011; Clapp 2015)— often fueled by misleading scientific or policy framings that pitch nature conservation and food production as incompatible (e.g. Vandermeer and Perfecto 2007; Grass et al. 2019). Some of the best known examples of landscape simplification are deforestation for soy production in the Amazon (Fearnside 2001) and Gran Chaco (Gasparri and Grau 2009), oil palm cultivation in Southeast Asia (Wicke et al. 2011). Less extreme examples of landscape simplification are far more widespread, and occur worldwide (e.g. Meehan et al. 2011; Jonason et al. 2013), for example agricultural intensification in Europe (Stoate et al. 2001).

While the destruction of ecological functions caused by landscape simplification is well documented, here we argue that in many cases, the effects on social-ecological aspects can be equally detrimental for sustainability. We draw on the relatively recent notion of relational values to provide a conceptual framework that hypothesizes ecological, social-ecological and social consequences resulting from landscape simplification. We suggest that landscape simplification has important but largely unexplored consequences for relational values. Neglecting such possible consequences, in turn, could undermine both present environmental management and future restoration potential in many landscapes.

Relational values have been proposed as a framing that can overcome the divide between nature having an inherent or intrinsic value, versus nature being of useful instrumental value to people (Muraca 2011). Relational values are defined as "preferences, principles and virtues about human-nature relationships" (Chan et al. 2018) and focus on the relational content of valuation (and not on the inherently relational process of valuation) (Himes and Muraca 2018). Instead of focusing on single value-providing entities and their beneficiaries, relational values emphasize the sum of collective values stemming from interactions within a social-ecological system (Muraca 2011). A key strength of a relational values perspective lies in the inclusion of environmentally mediated social relationships between individuals and groups of people (Chan et al. 2016), including elements of indigenous worldviews (Gould et al. 2019). Relational values acknowledge a plurality of sources of human well-being, and the concept is well equipped to include the diversity of inhabitants of places, including aspects of power and agency within their landscapes (Chapman et al. 2019). Relational values are heuristically divided into (1) the human collective, such as cultural identity, social cohesion, social responsibility and moral responsibility to non-humans; and (2) primarily individual values such as individual identity, stewardship eudaimonic (the care for nature fosters what I value as a good life) and stewardship principle/ virtue (it is right to protect nature) (sensu Chan et al. 2016; Pascual et al. 2017). 
The emergence of relational values (which adds to a vast body of research on related concepts such as sense of place (Trentelman 2009; e.g. Brehm et al. 2013) or landscape (e.g. ESF 2010) has facilitated growing recognition that landscape and environmental change influences human-nature connectedness as well as human relationships (Chan et al. 2016; Sheremata 2018). Here, we argue that landscape simplification can cause erosion of relational values. Leaving the links between the ecological, social-ecological and social dimensions of landscape change unattended could exacerbate a downward spiral of increasing inequality and disconnection from nature. Research shows that rapid landscape simplification can negatively influence inhabitants' emotional attachment to their 'home landscapes' as well as impacting the social interaction between those benefiting from the change and those that carry the (emotional) burden (Riechers et al. 2019). In this paper, we illustrate our perspective on relational values in the context of landscape simplification through four case studies from across the globe, and then discuss its implications for future research and practice in landscape sustainability science. We emphasize that our paper is not an indepth empirical investigation, but rather a conceptual contribution, in which we draw on selected empirical insights to substantiate and illustrate our argument.

\section{A relational values perspective on landscape change}

We propose that landscape simplification in rural landscapes-especially if it is rapid-can lead to the deterioration of ecological, social-ecological and social dimensions of the landscape's functioning. We acknowledge that urban or peri-urban systems could be equally interesting to examine from a relational values perspective, but in this paper, we choose to specifically focus on rural areas. We hypothesize that a typical diversified farming landscape has diverse ecological functions and strong relational values, such as strong human-nature connectedness and numerous values stemming from the flows of multiple types of ecosystem services. We further hypothesize strong relational values co-occurring with good social relationships and a strong sense of agency among resident groups in diversified rural landscapes (Fig. 1a). All of these relational values,

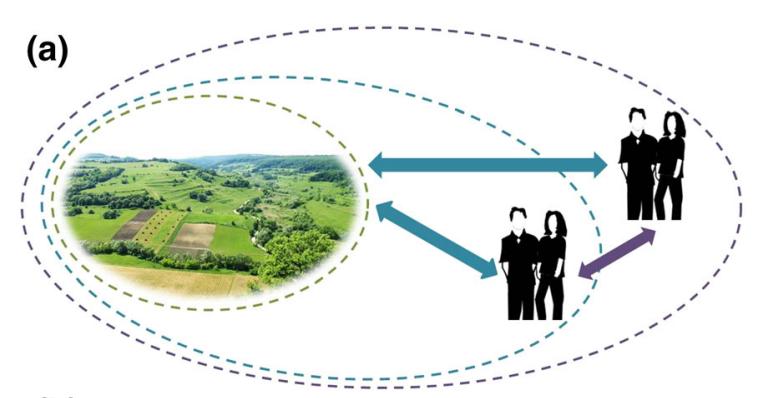

(b)

\begin{tabular}{ccc}
\hline Ecological & Social-Ecological & Social \\
\hline $\begin{array}{c}\text { Wild \& farmland } \\
\text { biodiversity }\end{array}$ & Human-nature & Social relationships \\
Crop diversity & Ecosystem services & Sense of agency \\
\hline
\end{tabular}

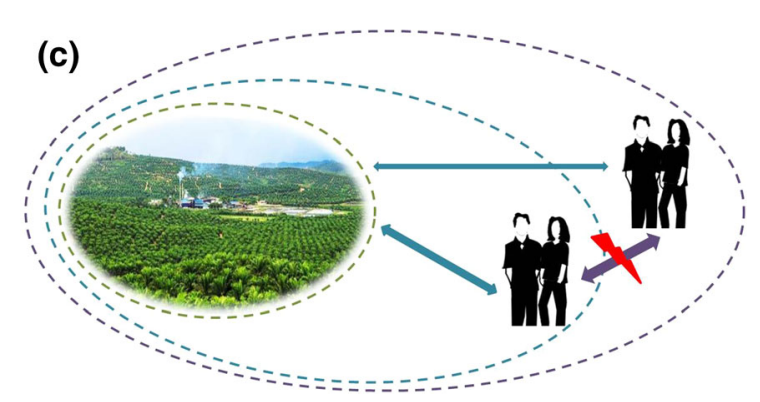

Fig. 1 Landscape simplification causes ecological, socialecological and social changes. a Original landscape state ( adapted from Chan et al. 2016). b Examples of ecological, social-ecological and social dimensions of landscape change. c Simplified landscape state. The width of the arrows denotes the hypothesized strength of a given connection; potential erosion or conflict is indicated by a lightning symbol. [Source Photo A: (CT. Hartel; Photo C: (C)CEphoto Uwe Aranas]

however, can be eroded through simplification of the social-ecological system (Fig. 1b), causing, in extreme cases, severe flow-on effects on humanhuman relationships (Fig. 1c). We thus hypothesize that, from a landscape sustainability science perspective, ecological changes to landscapes are intimately connected with social-ecological and social changes.

As a starting point, to illustrate our perspective, we consider a diversified farming landscape. This could be a traditional landscape where culture and nature have co-evolved, but it could also be a modern diversified farming landscape (Fig. 1a). In a diversified farming landscape, ecological functions are relatively stable, supporting elements of wild and farmland biodiversity, and comparatively high crop diversity (Tscharntke et al. 2005; Kremen et al. 2012). Humans and the environment in such landscapes are 
connected through a myriad of values, and inhabitants experience multiple benefits from a diverse range of ecosystem services (Horcea-Milcu et al. 2017). Regional identity and social relationships are often strong, and inhabitants actively exert agency to influence the landscape and its development trajectory.

We hypothesize that landscape simplification typically erodes various values associated with diversified farming landscapes (Fig. 1b). Around the world, landscapes are increasingly shaped by global (rather than only local) drivers (Wu 2013; Dorninger et al. 2017), including land use (Egli et al. 2018) and climate change (Mandryk et al. 2012; Prober et al. 2017), or questionable policy and scientific framings (Fischer et al. 2014a, b). These, in turn, stem from global population growth and changing consumption patterns, which foster massive geographically removed demand for agricultural goods, be they food, feed or fuel (Khoury et al. 2014). Landscape simplification is known to cause a loss of ecological functions-but there are also social-ecological consequences such as experiential, emotional and material disconnection of inhabitants from the landscape (Riechers et al. 2019; Balázsi et al. 2019). Moreover, cultural and individual identity and social cohesion can be partly mediated by human-nature connectedness (Chan et al. 2016). Hence, we postulate landscape simplification is also likely to have negative consequences for social relationships in many instances (Fig. 1c).

Last, there are likely flow-on effects on the sense of agency experienced by the inhabitants of a landscape undergoing structural simplification. Especially in landscapes with commodity crops, power relations play a major role in the distribution of benefits and burdens associated with landscape simplification (e.g. Berbés-Blázquez et al. 2016). Resources are often exploited by powerful (sometimes foreign) actors who leave locals with little economic revenue while shifting onto them the burden of provision and ecological impacts of the commodity crop. In this context, the sense of agency experienced by local people to meaningfully partake in the development of landscape trajectories can be expected to decline. Moreover, when access to land is restricted, or when land use strongly deviates from the ideals of inhabitants, a perceived loss of agency can go hand in hand with losses in regional identity and local ecological knowledge (Cundill et al. 2017; Chapman et al. 2019).
While we have separated ecological, social and social-ecological changes for simplicity in this paper, we are acutely aware that these spheres are intimately intertwined. Yet, we reason that certain aspects of landscape change are measurable entirely in ecological terms (e.g. biodiversity loss), while others are measurable entirely in social terms (e.g. loss of agency) - and yet others relate to links between the social and ecological realms (e.g. human-nature connectedness; ecosystem services). As such, we believe there is analytical value in not considering everything as "social-ecological", but rather noting that social-ecological change entails numerous interconnected dimensions.

\section{Illustration of the perspective}

We illustrate the plausibility of the perspective outlined above through four case studies. These describe a gradient from minor and gradual to major and rapid landscape simplification: Erdővidék (Transylvania, Romania), Landkreis Oldenburg (Lower Saxony, Germany), Wayanad (Kerala, India) and Abobo (Gambella, Ethiopia).

Erdővidék, as part of the Szeklerland, is a cultural landscape in southeastern Transylvania (Romania) that is dominated by smallholder farming. Studies in biophysically comparable landscapes in Transylvania have documented high levels of wild and farmland biodiversity and a wide range of ecosystem services (Hanspach et al. 2014). Changes in the last 100 years were driven by the socio-economic and political agenda of the central governance system, and rules that governed land use, management, property rights, local identity, social relationships, and in a broader sense the connection of communities to the landscape (Hartel et al. 2016). Three main periods can be distinguished that influenced landscape and value changes (Matei 2013): the pre-socialist (before 1947), socialist (1947-1989), and capitalistic/democratic period (after 1990). Historically, the Szeklerland was a privileged region of the Hungarian Kingdom with self-governed communities of peasants, where commons pool resources were regulated by village laws (Molnár et al. 2015). This medieval structure informally survived in Erdővidék until the newly formed socialist Romania reorganized its administrative divisions (1950-1968). This change influenced the local 
social-ecological system, both directly and indirectly through an altered socio-economic and cultural context (Csergö 2002). Forest became state property (1948), agricultural land was collectivized (1949-1962), and industrialization increased (1920-1970). The synergistic effects of these events caused value changes (e.g. loss of family farming, mechanization of agriculture and forestry, creation of jobs in industry) and weakened the connection of locals to the landscape materially (e.g. growing less of their own food), cognitively (e.g. declines in traditional, place-based knowledge) and experientially (e.g. through loss of access to nationalized state property and suspension of social gatherings traditionally held outdoors). In the 1990s, Romania restituted the pre-socialist land ownership structure (Verdery 1994). Although this contributed to property and land use fragmentation and disadvantaged business farming, it stimulated a revival of smallholder farming. In Erdővidék smallholder farming gained prominence because of people depended on the benefits from nature, and many still had an emotional connection to traditional practices. Relational values linked to traditional practices (e.g. joint hay making, pasture and forest cleaning) were revived in the 1990s, but have declined again since then. Unemployment sharply rose following the collapse of communist industries in the 1990s (Sandu et al. 2018). Alongside the political shift to capitalism, unsustainable land management (e.g. forests, pastures) increased. Despite numerous historical shocks, the local community today is still connected to nature in many ways, and local identity and social relationships are strong. While Erdővidék has maintained many of its traditional values to date, ongoing governance challenges and socioeconomic changes could ultimately pose a risk to these values in the long run (Horcea-Milcu et al. 2017).

The district of Oldenburg (Landkreis Oldenburg) is located in the mid-western part of Lower Saxony, Germany. Dominant natural land systems are "geest" areas including heathland (with mostly nutrient-poor sandy soils) and marshlands along the rivers (with nutrient rich, clayey soils). The district covers approximately 100,000 ha, of which two thirds are used for agriculture (LSN 2018a). Almost the whole district is part of the "nature park" Wildeshauser Geest, one of the largest nature parks in Germany. However, the nature park incorporates areas of different levels of conservation status and in general offers only weak protection to biodiversity. Over the last two decades national and European Union subsidies, especially for renewable energy production, in combination with a paradigm prioritizing economic growth, have fostered landscape simplification. As one example, the percentage of maize production (silage and grain maize production) grew from $\sim 18 \%$ in 1996 to $\sim 33 \%$ in 2015 (LSN 2018a, b), as the number of biogas plants increased from the first one built in 1998 to 88 in 2017 (existing, in construction, and in process on 4 July 2017, LK Oldenburg 2018). In terms of the ecological consequences, other studies from similar landscapes suggest a likely loss in biodiversity (e.g. in birds Guerrero et al. 2012; Brandt and Glemnitz 2014; or in insects Hallmann et al. 2017) and decreases in water and air quality (e.g. Velthof et al. 2014). Natural conditions combined with economic incentives have enabled a small number of farms to grow into large enterprises, outcompeting many smaller family farms. Today, competition for land between agriculture, village development, industry and nature conservation limits further increases in the size of landholdings; and high costs of leasing agricultural land as well as strict emission regulations further constrain the ongoing growth of farms. However, overall, smallholder farming has become increasingly unviable. The rise of industrial agriculture has caused tensions and conflicts between different groups of stakeholders, such as smallholder farmers, industrial farmers and nature conservation groups. The term "maizification" (in German "Vermaisung") has a negative normative and emotional connotation and has become widely used in the media and in polemic debates to describe major losses in crop diversity and landscape simplification (e.g. Linhart and Dhungel 2013). Our recent work in the district has uncovered a widespread feeling of lack of agency and frustration with the current landscape trajectory among landscape residents (Riechers et al. 2019). Nature connectedness and ecosystem service provision have been influenced by landscape simplification. Some human-nature connections have changed while others are being lost. For example, directly used local provisioning services, such as timber or locally produced food, appear to be declining. Place attachment was often discussed by inhabitants in relation to a structurally diverse landscape, and, hence, is seen as being threatened by landscape simplification. Inhabitants perceived a loss 
of agency regarding "their" landscape and home which was driven by, often unidentified, outside forces that seemed to be changing the local social-ecological system in unsustainable ways.

Wayanad District is located in the north of Kerala State, India. Wayanad is a biocultural hotspot (Pretty et al. 2009; Brosius and Hitchner 2010) and became a UNESCO World heritage site in 2012 (UNESCO 2012). While it is home to many threatened species and ecosystems (Myers et al. 2000), it also hosts a large indigenous population (Rath 2006). It is an undulating landscape, and approximately $97 \%$ of Wayanad are under agricultural use, mainly subsistence farming and smallholder plantations (Santhoshkumar and Ichikawa 2010). Beginning in the 1990s, agriculturalists all over India were hit by the agrarian crisis. In the case of Wayanad, the most important events were: (1) the rise and fall of pepper, vanilla and coffee cultivation and a coinciding ecological crisis (George and Krishnaprasad 2006; Münster 2012); (2) the reduction of import restrictions on agrarian products (Lerche 2011); (3) the impact of the Green Revolution (Pandey et al. 2010; Suma 2014); and (4) the commercialization of agriculture (Jose and Padmanabhan 2016). Due to agricultural intensification, Wayanad lost 160 rice, as well as several pepper, banana, and vegetable varieties $(\mathrm{Ku}-$ mar and Nair 2004; Suma 2014). The heavy overuse of chemicals, especially in pepper production, left the soil in many areas damaged beyond repair (Münster 2012). Furthermore, chemical use and land use change have resulted in a reduction of water and soil quality, and have been linked to a general decline in wild and farmland biodiversity (Kumar 2005). A poorly organized local rice market and the absence of rice mills in Wayanad have increased transaction costs for family farmers, making traditional rice cultivation increasingly unattractive (Jose and Padmanabhan 2016). The abolition of bonded labor increased expenses for laborers, and government schemes supporting the rural poor do not extend to agricultural laborerswhich further aggravated the labor shortage, making traditional rice cultivation even less profitable. As a consequence, many rice farmers have converted their fields into cash crop plantations (Jose and Padmanabhan 2016). Intensified agriculture has created tensions between organic farmers and commercial farmers. Our studies in the area found that farmers perceived a link between increasing health problems and the use of agrochemicals. As a result, women are often prohibited from working in cash crop fields, and this has reduced their incomes and independence (Thottathil 2012; Betz personal communications during fieldwork in 2010 and 2011). Losses in wild and farmland biodiversity have also entailed nutritional changes. Especially the former forest nomads continued to collect edible plants and hunting game in the forest until recently (Suma 2014). Forest losses and a hunting ban, however, heavily restrict these practices now (Münster and Vishnudas 2012), increasing the economic burden of the locals (Betz et al. 2014). Yet, many local people still maintain sacred places in the forest and celebrate their religious ceremonies which are closely linked to rice cultivation (Betz et al. 2014; Suma 2014; Kunze 2017). Landscape simplification, access to higher education, different laws and regulations have changed the sense of agency perceived by local people. Moreover, gender relations, livelihood strategies and social order have changed (e.g. from matrilineal to patrilineal inheritance; from joint to nuclear families) (Suma 2014; Kunze and Momsen 2015; Kunze 2017), with likely negative repercussions for relational values.

Abobo district is located in Anuak zone, within Gambella region in western Ethiopia. Abobo district had long been known for its rich biodiversity, particularly of birds and mammals. The establishment of Gambella National Park in 1964 on approximately 5000 square kilometers along the Alwero River was intended to provide habitat to internationally important wildlife, and to act as a corridor for a major wildlife migration route between Ethiopia and South Sudan (Rahmato 2011). The Anuak people are the dominant indigenous agrarian community in the district. Smallholder agriculture is their dominant livelihood strategy, and the Anuak people are intimately connected with their land-which they consider a source of livelihood, and of cultural, ancestral and spiritual values (Horne et al. 2011). Moreover, water, wildlife and forest resources traditionally provided many ecosystem services to the Anuak people, including materials to build their homes, medicines and food, as well as providing a source of resilience against environmental shocks. In the last 15 years, driven by an agenda to stimulate economic growth, the government of Ethiopia has encouraged the expansion of large-scale private agricultural investors in Abobo district (Hussien 2004; Yasin 
2010; Van der Wulp 2013). As a result, large areas of land, including farmland used by local people, communal land, and parts of Gambella National Park, were transferred to private investors such as the Saudi Arabia based "Saudi Star PLC" (10,000 ha) and Indian based "Karaturi PLC" (300,000 ha) (Abbink 2011; Rahmato 2011; Horne et al. 2011). Large-scale agricultural land acquisition has transformed the landscape into an intensive rice monoculture, forcefully removing local inhabitants, with numerous social, economic and ecological impacts (Rahmato 2011; Horne et al. 2011; Van der Wulp 2013; Baumgartner 2017). To the local Anuak people, land is closely tied to their identity and is an important spiritual asset, such that forced eviction has caused severe cultural and spiritual disconnection. Horne et al. (2011) suggested that the land transfer had robbed the community of their identity, created a disconnection from their ancestors, and from future generations to whom community values and traditions can no longer be readily transferred. Moreover, landscape simplification has caused conflicts: between the local people and the investors-leading to the violent destruction of infrastructure; between the local people and migrant workers coming from other parts of the country to work for the investors or on related infrastructure projects; and with adjacent pastoral communities, on whose traditional lands displaced Anuak people began to clear land for agriculture (Abbink 2011; Rahmato 2011; Horne et al. 2011). Although surplus food production was claimed to abate food insecurity, the crops grown are actually destined for international markets and therefore do not benefit local people (Horne et al. 2011). The loss of access to economically important ecosystem services (such as honey and fish), and livelihood assuring activities (such as gathering food, fuelwood, medicines, and occasional hunting of wildlife) have endangered the lives of the indigenous people (Horne et al. 2011; Rahmato 2011). Ecologically, landscape simplification has caused habitat loss and fragmentation, degradation of water resources, and clearing of forests (Abbink 2011; Horne et al. 2011; Rahmato 2011).

In combination, these case studies illustrate a gradient in ecological, social-ecological and social deterioration resulting from landscape simplification (Fig. 2). A key proposition is that all three dimensions of landscape change-ecological, social-ecological and social-appear partly predictable, and somewhat proportional to the speed and intensity of landscape simplification. We intentionally chose an extreme end point-Gambella-in our illustration, but we emphasize that the gradient of intensity of change is what is particularly interesting here, not the extremes as such. If what we propose here turns out to be generally applicable, it shows yet more trade-offs to landscape simplification than are typically recognized. Increasingly industrial crop production thus not only results in a loss of biodiversity and other types of ecosystem services (Foley et al. 2005), but landscape simplification also systematically and predictably undermines human-nature connectedness and social relations, that is, relational values. While one could argue this is a necessary trade-off in the face of a global increase in the demand for food, it is worth highlighting that most of the increase in global demand is related to increasingly meat- and oil-rich diets (Khoury et al. 2014), and landscape simplification thus is unlikely to improve access to food for those who actually need it.

\section{Implications and future research}

Landscape sustainability science encourages the simultaneous analysis of interconnected ecological, social and economic changes in a given place $(\mathrm{Wu}$ 2013). As our perspective has shown, this lens opens spaces for new types of landscape analyses-in this case, through using the concept of relational values. The perspective outlined above is based on myriad long-standing scientific traditions and disciplines (e.g. Déjeant-Pons 2006; Olwig 2007; ESF 2010) and is not an analytical endpoint, but should be seen as an empirically inspired proposition of how landscape simplification can erode relational values. Future research could further detail and unpack-or potentially refute - this perspective. We propose future research could examine: (i) interactions between social and ecological variables, (ii) time lags in changes in relational values, and (iii) implications for restoration projects.

First, focusing on interactions that alter relational values could help to scrutinize, for example, which types of agricultural system might best link ecological, social-ecological and social variables in desired ways. To comprehensively investigate interactions between those variables, we propose taking a "leverage points" perspective (Meadows 1999). This perspective seeks 


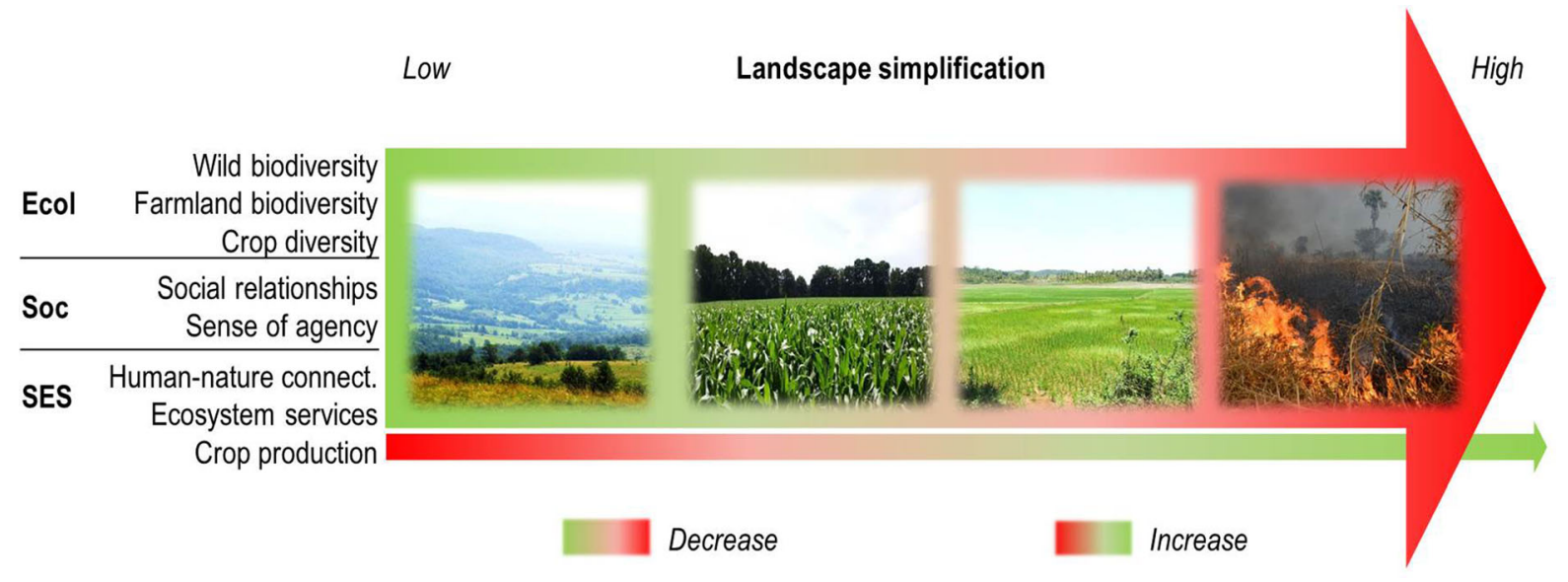

Fig. 2 Case studies describe a gradient from little simplification and slow landscape change to rapid, major landscape simplification (from left to right: Erdővidék, Landkreis Oldenburg, Wayanad, Gambella). Unlike the other variables depicted, the ecosystem service of crop production increases with landscape simplification. "Social relationships" = quality of social relationships; Human-nature connect. = human-nature

to identify strategic points to intervene in a system, ranging from shallow leverage points, such as parameters and feedbacks, to deep leverage points, such as worldviews and paradigms (Abson et al. 2017). A leverage points perspective helps to better understand how shallow and deep changes interact at different levels of systemic depth-describing how one type of change in a system precipitates another (Fischer and Riechers 2019). Deep leverage points for sustainability transformation are often neglected in research (Dorninger et al. 2020). Our preliminary analysis suggests that export-oriented, industrial systems erode landscape values at multiple levels of systemic depth, in at least three dimensions (ecological, socialecological, and social).

Second, we believe it would be useful to study possible time lags in the impacts of landscape change on relational values. Some relational values, such as regional identity or a deep-rooted sense of responsibility for a region, may erode only slowly in response to landscape change (e.g. Horcea-Milcu et al. 2017). While in landscapes with more gradual and slower simplification, inhabitants might also change their values and start appreciating newly emerging landscape features (e.g. the beauty of rape seed flowers, or the wide view after a forest clearing) (e.g. Selman 2010), we hypothesize such adjustment to diminish the more rapid and extreme the landscape simplification connectedness (sensu Ives et al. 2018); Ecol = ecological dimensions of landscape change; Soc $=$ social dimensions of landscape change; SES = social-ecological dimensions of landscape change. [Due to the conflicts in the area, picture of Gambella are difficult to publish. This photograph shown here depicts land-cover change through large scale burning. Source Photo D (on the right): CJoerg Boethling/Alamy Stock Photo]

will be. Studying such lag effects in responses to landscape change is important in its own right, but also because lag effects may provide institutional memory and a window of opportunity in which to restore social-ecological sustainability after the onset of landscape change.

Third, and following directly from the previous point, how could knowledge on relational values help with restoration projects? Relational values can have both positive and negative effects on the implementation and success of conservation and sustainability projects (Cundill et al. 2017; Klain et al. 2017; Jax et al. 2018). For example, drawing on local people's expressions of human-nature connectedness and social relationships could be a powerful way to tap into underlying motivation to help people restore 'their' landscape, drawing on, as well as strengthening, local identity and sense of agency (Chapman et al. 2019; Riechers et al. 2019). Moreover, the concept of relational values can help shed light on power relations between people and organizations regarding differential access to and distribution of benefits and burdens (Berbés-Blázquez et al. 2016), and could also help to foster a social-ecological approach towards ecosystem restoration (Fischer et al. forthcoming).

Although we caution that the ideas presented in this paper require further investigation, we propose an initial set of preliminary recommendations for policy 
Box 1 Preliminary recommendations for policy and practice arising from a relational values perspective on landscape simplification

Landscape simplification is not just an ecological problem, and hence needs to be managed with attention to its social-ecological and social context. While biodiversity loss and a decrease in ecosystem services in response to landscape simplification have become common knowledge, social-ecological interactions demand more attention. Policy and management that target biodiversity conservation and ecological restoration should be aware of the interlinkages between a landscape and the people inhabiting it

Human-nature connectedness and social relationships need to be carefully considered in management plans, because they can work in favor of conservation outcomes, but could also undermine them. We expect strong associations between the multifacetted experiential and emotional connections inhabitants have with their landscape, their regional identity, and their social engagement in the region. If these relations are strong, they can support conservation or restoration initiatives, but if they are weak, they could significantly hinder the effective implementation of new policies or management approaches

Local agency is a likely key ingredient to landscape sustainability, and should be actively fostered in conservation and restoration projects. Regional identity, solidarity with other local people, and the sense of responsibility for a landscape as 'home' can be seriously eroded as a result of landscape simplification, especially when powerful, external actors directly drive landscape change. A loss of agency could lead to apathy and might cause disinterest, disregard or even disrespect for local community and the landscape

and practice (Box 1). We emphasize these must not be implemented blindly, but should be carefully scrutinized on a case-by-case basis. In conclusion, we urge that it is time to look at landscape simplification more holistically than only from a biodiversity or ecosystem services perspective. Within the context of landscape sustainability science in particular, relational values may be a useful concept to facilitate such investigations.

Acknowledgements Open Access funding provided by Projekt DEAL. We thank Tibor Hartel, Joerg Boethling and Uwe Aranas (CEphoto) for providing landscape photographs. This research was supported by the Volkswagenstiftung and the Niedersächsisches Ministerium für Wissenschaft und Kultur (Grant Number A112269), and partly draws on work undertaken in a large transdisciplinary research project (Leverage Points for Sustainability Transformation). The author(s) acknowledge and thank all project members for their ideas and input in the early stages of this work, even where they are not listed as authors. Full details of project members and their research are available at https://leveragepoints.org. $\mathrm{AB}$ is currently involved in the BiodivERsA-FACCE2014-47 project.

Open Access This article is licensed under a Creative Commons Attribution 4.0 International License, which permits use, sharing, adaptation, distribution and reproduction in any medium or format, as long as you give appropriate credit to the original author(s) and the source, provide a link to the Creative Commons licence, and indicate if changes were made. The images or other third party material in this article are included in the article's Creative Commons licence, unless indicated otherwise in a credit line to the material. If material is not included in the article's Creative Commons licence and your intended use is not permitted by statutory regulation or exceeds the permitted use, you will need to obtain permission directly from the copyright holder. To view a copy of this licence, visit http://creativecommons.org/licenses/by/4.0/.

\section{References}

Abbink J (2011) Land to the foreigners: economic, legal, and socio-cultural aspects of new land acquisition schemes in Ethiopia. J Contemp Afr Stud 29:513-535

Abson DJ, Fischer J, Leventon J, Newig J, Schomerus T, Vilsmaier $\mathrm{U}$, von Wehrden $\mathrm{H}$, Abernethy $\mathrm{P}$, Ives $\mathrm{CD}$, Jager NW, Lang DJ (2017) Leverage points for sustainability transformation. Ambio 46:30-39

Balázsi Á, Riechers M, Hartel T, Leventon J, Fischer J (2019) The impacts of social-ecological system change on humannature connectedness: a case study from Transylvania. Rom Land Use Policy 89:104232

Baumgartner P (2017) The impacts of large scale land acquisition on East Africa on poverty reduction and rural economy: studies in Ethiopia and Uganda. Dissertation, Center for Development Research, University of Bonn.

Brandt K, Glemnitz M (2014) Assessing the regional impacts of increased energy maize cultivation on farmland birds. Environ Monit Assess 186(2):679-697

Berbés-Blázquez M, González JA, Pascual U (2016) Towards an ecosystem services approach that addresses social power relations. Curr Opin Environ Sustain 19:134-143

Betz L, Kunze I, Prajeesh P, Suma TR (2014) The social-ecological web: a bridging concept for transdisciplinary research. Curr Sci 107:572-579

Brehm JM, Eisenhauer BW, Stedman RC (2013) Environmental concern: examining the role of place meaning and place attachment. Soc Nat Resour 26:522-538

Brosius JP, Hitchner SL (2010) Cultural diversity and conservation. Int Soc Sci J 61:141-168

Chan KM, Gould RK, Pascual U (2018) Editorial overview: relational values: what are they, and what's the fuss about? Curr Opin Environ Sustain 35:A1-A7

Chan KMA, Balvanera P, Benessaiah K, Chapman M, Díaz S, Gómez-Baggethun E, Gould R, Hannahs N, Jax K, Klain S, Luck GW (2016) Opinion: why protect nature? Rethinking values and the environment. Proc Natl Acad Sci USA 113:1462-1465

Chapman M, Satterfield T, Chan KMA (2019) When value conflicts are barriers: can relational values help explain 
farmer participation in conservation incentive programs? Land Use Policy 82:464-475

Clapp J (2015) Distant agricultural landscapes. Sustain Sci $10: 305-316$

Csergő Z (2002) Beyond ethnic division: majority-minority debate about the postcommunist state in Romania and Slovakia. East Eur Polit Soc 16:1-29

Cundill G, Bezerra JC, De Vos A, Ntingana N (2017) Beyond benefit sharing: place attachment and the importance of access to protected areas for surrounding communities. Ecosyst Serv. https://doi.org/10.1016/j.ecoser.2017.03.011

Déjeant-Pons M (2006) The European landscape convention. Landsc Res 31:363-384

Dorninger C, Abson DJ, Apetrei CI, Derwort P, Ives CD, Klaniecki K, Lam DP, Langsenlehner M, Riechers M, Spittler $\mathrm{N}$, von Wehrden H (2020) Leverage points for sustainability transformation: a review on interventions in food and energy systems. Ecol Econ 171:106570

Dorninger C, Abson DJ, Fischer J, von Wehrden H (2017) Assessing sustainable biophysical human-nature connectedness at regional scales. Environ Res Lett 12:055001

Egli L, Meyer C, Scherber C, Kreft H, Tscharntke T (2018) Winners and losers of national and global efforts to reconcile agricultural intensification and biodiversity conservation. Glob Change Biol 24:2212-2228

ESF (2010) Landscape in a changing world. Bridging divides, integrating disciplines, serving society. Science policy briefing 41. European Science Foundation ESF-COST, Strasbourg/Brussels

FAO (2011) Report of the panel of eminent experts on ethics in food and agriculture. FAO (Food and Agriculture Organization of the United Nations), Rome

Fearnside PM (2001) Soybean cultivation as a threat to the environment in Brazil. Environ Conserv 28:23-38

Fischer J, Abson DJ, Butsic V, Chappell MJ, Ekroos J, Hanspach J, Kuemmerle T, Smith HG, von Wehrden H (2014a) Land sparing versus land sharing: moving forward. Conserv Lett 7:149-157

Fischer J, Manning AD, Steffen W, Rose DB, Daniell K, Felton A, Garnett S, Gilna B, Heinsohn R, Lindenmayer DB, MacDonald B, Mills F, Newell B, Reid J, Robin L, Sherren K, Wade A (2007) Mind the sustainability gap. Trends Ecol Evol 22:621-624

Fischer J, Martín-Lopéz B, Temperton V, Riechers M (forthcoming) The decade of social-ecological restoration

Fischer J, Riechers M (2019) A leverage points perspective on sustainability. People Nat. https://doi.org/10.1002/pan3.13

Fischer J, Sherren K, Hanspach J (2014b) Place, case and process: applying ecology to sustainable development. Basic Appl Ecol 15:187-193

Foley JA, Defries R, Asner GP, Barford C, Bonan G, Carpenter SR, Chapin FS, Coe MT, Daily GC, Gibbs HK, Helkowski JH, Holloway T, Howard EA, Kucharik CJ, Monfreda C, Patz JA, Prentice IC, Ramankutty N, Snyder PK (2005) Global consequences of land use. Science 309:570-574

Foley JA, Ramankutty N, Brauman KA, Cassidy ES, Gerber JS, Johnston M, Mueller ND, O'Connell C, Ray DK, West PC, Balzer C, Bennett EM, Carpenter SR, Hill J, Monfreda C, Polasky S, Rockström J, Sheehan J, Siebert S, Tilman D, Zaks DPM (2011) Solutions for a cultivated planet. Nature 478:337-342
Forman RTT, Wilson EO (1995) Land mosaics: the ecology of landscapes and regions. https://doi.org/10.1017/ 9781107050327

Gasparri NI, Grau HR (2009) Deforestation and fragmentation of Chaco dry forest in NW Argentina (1972-2007). For Ecol Manag 258:913-921

George J, Krishnaprasad P (2006) Agrarian distress and farmers' suicide in the tribal district of Wayanad. Soc Sci 34:70-85

Gould RK, Pai M, Muraca B, Chan KMA (2019) He 'ike 'ana ia i ka pono (it is a recognizing of the right thing): how one indigenous worldview informs relational values and social values. Sustain Sci 14:1213-1232

Grass I, Loos J, Baensch S, Batáry P, Librán-Embid F, Ficiciyan A, Klaus F, Riechers M, Rosa J, Tiede J, Udy K (2019) Land-sharing/-sparing connectivity landscapes for ecosystem services and biodiversity conservation. People Nat. https://doi.org/10.1002/pan3.21

Green RE, Cornell SJ, Scharlemann JPW, Balmford A (2005) Farming and the fate of wild nature. Science 307:550-555

Guerrero I, Morales MB, Oñate JJ, Geiger F, Berendse F, de Snoo G, Eggers S, Pärt T, Bengtsson J, Clement LW, Weisser WW (2012) Response of ground-nesting farmland birds to agricultural intensification across Europe: landscape and field level management factors. Biol Conserv 152:74-80

Hallmann CA, Sorg M, Jongejans E, Siepel H, Hofland N, Schwan H, Stenmans W, Müller A (2017) More than 75 percent decline over 27 years in total flying insect biomass in protected areas. PLoS ONE 12:e0185809

Hanspach J, Hartel T, Milcu AI, Mikulcak F, Dorresteijn I, Loos $\mathrm{J}$, von Wehrden $\mathrm{H}$, Kuemmerle $\mathrm{T}$, Abson D, KovácsHostyánszki A, Báldi A, Fischer J (2014) A holistic approach to studying social-ecological systems and its application to southern Transylvania. Ecol Soc 19(4):32

Hartel T, Olga Réti K, Craioveanu C, Gallé R, Popa R, Ioniţă A, Demeter L, Rákosy L, Czúcz B (2016) Rural social-ecological systems navigating institutional transitions: case study from Transylvania (Romania). Ecosyst Health Sustain. https://doi.org/10.1002/ehs2.1206

Himes A, Muraca B (2018) Relational values: the key to pluralistic valuation of ecosystem services. Curr Opin Environ Sustain 35:1-7

Horcea-Milcu AI, Abson DJ, Dorresteijn I, Loos J, Hanspach J, Fischer J (2017) The role of co-evolutionary development and value change debt in navigating transitioning cultural landscapes: the case of Southern Transylvania. J Environ Plan Manag 61:1-18

Horne F, Mousseau F, Metho O, Mittal A, Shepard D (2011) Understanding land investment deals in Africa. The Oakland Institute, Oakland

Hussein J (2004) The politics of land tenure in Ethiopian history: experience from the south. Centre for International Environmental and Development Studies Agricultural University of Norway, Viken

Ives CD, Abson DJ, von Wehrden H, Dorninger C, Klaniecki K, Fischer J (2018) Reconnecting with nature for sustainability. Sustain Sci 13:1389-1397

Jax K, Calestani M, Chan KM, Eser U, Keune H, Muraca B, O'Brien L, Potthast T, Voget-Kleschin L, Wittmer H (2018) Caring for nature matters: a relational approach for 
understanding nature's contributions to human well-being. Curr Opin Environ Sustain 35:22-29

Jonason D, Smith HG, Bengtsson J, Birkhofer K (2013) Landscape simplification promotes weed seed predation by carabid beetles (Coleoptera: Carabidae). Landsc Ecol 28:487-494

Jose M, Padmanabhan M (2016) Dynamics of agricultural land use change in Kerala: a policy and social-ecological perspective. Int J Agric Sustain 14:307-324

Kates RW, Clark WC, Corell R, Hall JM, Jaeger CC, Lowe I, McCarthy JJ, Schellnhuber HJ, Bolin B, Dickson NM, Faucheux S, Gallopin GC, Grübler A, Huntley B, Jäger J, Jodha NS, Kasperson RE, Mabogunje A, Matson P, Mooney H, Moore B 3rd, O'Riordan T, Svedlin U (2001) Environment and development. Sustainability science. Science 292:641-642

Khoury CK, Bjorkman AD, Dempewolf H, Ramirez-Villegas J, Guarino L, Jarvis A, Rieseberg LH, Struik PC (2014) Increasing homogeneity in global food supplies and the implications for food security. Proc Natl Acad Sci USA 111:4001-4006

Klain SC, Olmsted P, Chan KMA, Satterfield T (2017) Relational values resonate broadly and differently than intrinsic or instrumental values, or the New Ecological Paradigm. PLoS ONE 12:e0183962

Kremen C, Iles A, Bacon C (2012) Diversified farming systems: an agroecological, systems-based alternative to modern industrial agriculture. Ecol Soc 17:44

Kumar BM (2005) Land use in Kerala: changing scenarios and shifting paradigms. J Trop Agric 42:1-12

Kumar BM, Nair PKR (2004) The enigma of tropical homegardens. Agrofor Syst 61-62:135-152

Kunze I, Momsen J (2015) Exploring gendered rural space of agrobiodiversity and management. In: Coles A, Gray L, Momsen JH (eds) The Routledge handbook of gender and development. Routledge, London

Kunze I (2017) Dualisms shaping human-nature relations: discovering the multiple meanings of social-ecological change in Wayanad. Agric Hum Values 34:983-994

Lerche J (2011) Agrarian crisis and Agrarian questions in India. J Agrar Change 11:104-118

LSN Landesamt für Statistik Niedersachsen (2018a) Katasterfläche nach Nutzungsarten (17) der tatsächlichen Nutzung (Gemeinde; Zeitreihe). Gebietsstand: 1.1.2015. Landwirtschaftliche Fläche (ohne Moor \& Heide) von 1997, 2015. https://www1.nls.niedersachsen.de/statistik/html/ default.asp. Accessed 3 May 2018

LSN Landesamt für Statistik Niedersachsen (2018b) Agrarstrukturerhebung (ab 1999), Maisanbau von 1995-2016. Accessed 3 May 2018

Landkreis Oldenburg (2018) Planen und Bauen/Bauen im Landkreis Oldenburg/Biogasanlagen. www.oldenburgkreis.de/portal/seiten/biogasanlagen-900000059-21700. html. Accessed 8 Mar 2018

Lang DJ, Wiek A, Bergmann M, Stauffacher M, Martens P, Moll P, Swilling M, Thomas CJ (2012) Transdisciplinary research in sustainability science: practice, principles, and challenges. Sustain Sci 7:25-43

Linhart E, Dhungel A (2013) Das Thema Vermaisung im öffentlichen Diskurs(The topic of maizification in the public discourse). Berichte über die Landwirtschaft, Band 91, Ausgabe 2. Agrarwissenschaft, Forschung, Praxis

Mandryk M, Reidsma P, van Ittersum MK (2012) Scenarios of long-term farm structural change for application in climate change impact assessment. Landsc Ecol 27:509-527

Matei A (2013) Public administration in Romania: historical milestones and daily realities. In: Liebert S, Condrey SE, Goncharov D (eds) Public administration in post-communist countries: former Soviet Union, central and Eastern Europe, and Mongolia. CRC Press, Boca Raton

Meadows DH (1999) Leverage points: places to intervene in a system. The Sustainability Institute, Hartland

Meehan TD, Werling BP, Landis DA, Gratton C (2011) Agricultural landscape simplification and insecticide use in the Midwestern United States. Proc Natl Acad Sci USA 108:11500-11505

Molnár Z, Gellény K, Margóczi K, Biró M (2015) Landscape ethnoecological knowledge base and management of ecosystem services in a Székely-Hungarian pre-capitalistic village system (Transylvania, Romania). J Ethnobiol Ethnomed 11:3

Muraca B (2011) The map of moral significance: a new axiological matrix for environmental ethics. Environ Values 20:375-396

Münster D (2012) Farmers' suicides and the state in India: conceptual and ethnographic notes from Wayanad, Kerala. Contrib Indian Sociol 46:181-208

Münster U, Vishnudas S (2012) In the Jungle of Law. Adivasi Rights and Implementation of Forest Rights Act in Kerala. Econ Polit Wkly 7:38-45

Myers N, Mittermeier RA, Mittermeier CG, daFonseca GAB, Kent J (2000) Biodiversity hotspots for conservation priorities. Nature 403:853-858

Olwig KR (2007) The practice of landscape "Conventions" and the just landscape: the case of the European landscape convention. Landsc Res 32:579-594

Pandey S, Byerlee D, Dawe D, Dobermann A, Mohanty S, Rozelle S, Hardy B (eds) (2010) Rice in the global economy. Strategic research and policy issues for food security. International Rice Research Institute, Philippines

Pascual U, Balvanera P, Díaz S, Pataki G, Roth E, Stenseke M, Watson RT, Dessane EB, Islar M, Kelemen E, Maris V (2017) Valuing nature's contributions to people: the IPBES approach. Curr Opin Environ Sustain 26-27:7-16

Pretty J, Adams B, Berkes F, De Athayde SF, Dudley N, Hunn E, Maffi L, Milton K, Rapport D, Robbins P, Sterling E (2009) The intersections of biological diversity and cultural diversity: towards integration. Conserv Soc 7:100-112

Prober SM, Colloff MJ, Abel N, Crimp S, Doherty MD, Dunlop M, Eldridge DJ, Gorddard R, Lavorel S, Metcalfe DJ, Murphy HT (2017) Informing climate adaptation pathways in multi-use woodland landscapes using the values-rulesknowledge framework. Agr Ecosyst Environ 241:39-53

Rahmato D (2011) Land to investors: large-scale land transfers in Ethiopia. Forum for Social Studies, Addis Ababa

Rath GC (2006) Tribal development in India. The contemporary debate. Sage Publications, New Delhi, Thousand Oaks

Riechers M, Henkel W, Engbers M, Fischer J (2019) Stories of favourite places in public spaces: emotional responses to landscape change. Sustainability 11:3851 
Sandu D, Toth G, Tudor E (2018) The nexus of motivationexperience in the migration process of young Romanians. Popul Space Place 24(1):e2114

Santhoshkumar AV, Ichikawa K (2010) Homegardens: Sustainable land use systems in Wayanad, Kerala, India. In: Bélair C, Ichikawa K, Wong BYL, Mulongoy KJ (eds) Sustainable use of biological diversity in socio-ecological production landscapes. Background to the 'Satoyama Initiative for the benefit of biodiversity and human well-being'. Montreal: Secretariat of the Convention on Biological Diversity, Technical Series, 52:125-128.

Selman P (2010) Learning to love the landscapes of carbonneutrality. Landsc Res 35:157-171

Sheremata M (2018) Listening to relational values in the era of rapid environmental change in the Inuit Nunangat. Curr Opin Environ Sustain 35:75-81

Stoate C, Boatman ND, Borralho RJ, Carvalho CR, De Snoo GR, Eden P (2001) Ecological impacts of arable intensification in Europe. J Environ Manag 63:337-365

Suma TR (2014) Customary vs state laws of land governance: Adivasi joint family farmers seek policy support. International Land Coalition, Rome

Thottathil SE (2012) Incredible Kerala? A political ecological analysis of organic agriculture in the "Model for Developement". Dissertation, University of California, Berkeley, California

Trentelman CK (2009) Place attachment and community attachment: a primer grounded in the lived experience of a community sociologist. Soc Nat Resour 22:191-210

Tscharntke T, Klein AM, Kruess A, Steffan-Dewenter I, Thies C (2005) Landscape perspectives on agricultural intensification and biodiversity-ecosystem service management. Ecol Lett 8:857-874
UNESCO (2012) Western Ghats. www.whc.unesco.org/en/list/ 1342. Accessed 8 May 2013

Vandermeer J, Perfecto I (2007) The agricultural matrix and a future paradigm for conservation. Conserv Biol 21:274-277

Van der Wulp ACE (2013) The role of the state in facilitating land grabs in Ethiopia. Wageningen University, Wageningen

Velthof GL, Lesschen JP, Webb J, Pietrzak S, Miatkowski Z, Pinto M, Kros J, Oenema O (2014) The impact of the nitrates directive on nitrogen emissions from agriculture in the EU-27 during 2000-2008. Sci Total Environ. https:// doi.org/10.1016/j.scitotenv.2013.04.058

Verdery K (1994) Elasticity of land: problems of property restitution in Transylvania. Slav Rev 53:1071-1109

Wicke B, Sikkema R, Dornburg V, Faaij A (2011) Exploring land use changes and the role of palm oil production in Indonesia and Malaysia. Land Use Policy 28:193-206

Wu J (2013) Landscape sustainability science: ecosystem services and human well-being in changing landscapes. Landsc Ecol 28:999-1023

Wu J, Hobbs R (2002) Key issues and research priorities in landscape ecology: an idiosyncratic synthesis. Landsc Ecol 17:355-365

Yasin A (2010) Large scale transnational land acquisition in Ethiopia-is it an acceleration for development? The case of Bako and Gambella regions in Ethiopia. International Institute of Social Studies, The Hague

Publisher's Note Springer Nature remains neutral with regard to jurisdictional claims in published maps and institutional affiliations. 